\title{
Flood protection as a key-component of the environmental restoration of Canal del Dique, Colombia
}

\author{
Marius Sokolewicz ${ }^{1, a}$, Eisse Wijma ${ }^{1}$, Harm Nomden ${ }^{1}$, Tjeerd Driessen ${ }^{1}$, Quintijn van Agten ${ }^{1}$ and Fortunato Carvajal ${ }^{2}$ \\ ${ }^{1}$ Royal HaskoningDHV, P.O. Box 1132, 3800 BC Amersfoort, the Netherlands \\ ${ }^{2}$ Royal HaskoningDHV, Calle 90 No 19-41 Oficina 801, Bogotá, Colombia
}

\begin{abstract}
Canal del Dique is a man-made distributary of Rio Magdalena. After its widening in 1980's environmental degradation caused by abundant sediment load and changes to hydrology took a catastrophic form. In 2010, the Canal's dike breached and 35,000 ha of land were flooded. In 2013 a huge effort to restore the environment in the Canal del Dique system and to flood-proof the villages was started. An integrated approach was adopted to provide an optimal solution for flood control, environment, fresh water supply and navigation. In order to prepare restoration plans, an extensive hydrologic and hydraulic assessment was carried out. 1D, 2D and 3D numerical models were developed to answer different questions, to evaluate different alternatives and to enable selection of optimal solutions. To assess the flood risk, a hindcast of 2010 flood was carried out. A solution was designed in which the inlet of water from the Magdalena River is regulated by a control structure, managed by an automated system based on SCADA and Delft-FEWS flood forecasting software and advanced statistics.
\end{abstract}

\section{Introduction}

\subsection{Historical background}

The Canal del Dique is a man-made connection between the Río Magdalena and the Caribbean Sea near Cartagena in Colombia initiated in 1650. Figure 1 illustrates that Canal del Dique is not just a canal. It is a system of interconnected water bodies (lakes and swamps known as ciénagas); the ciénagas drain into the canal via small canals (known as caños).

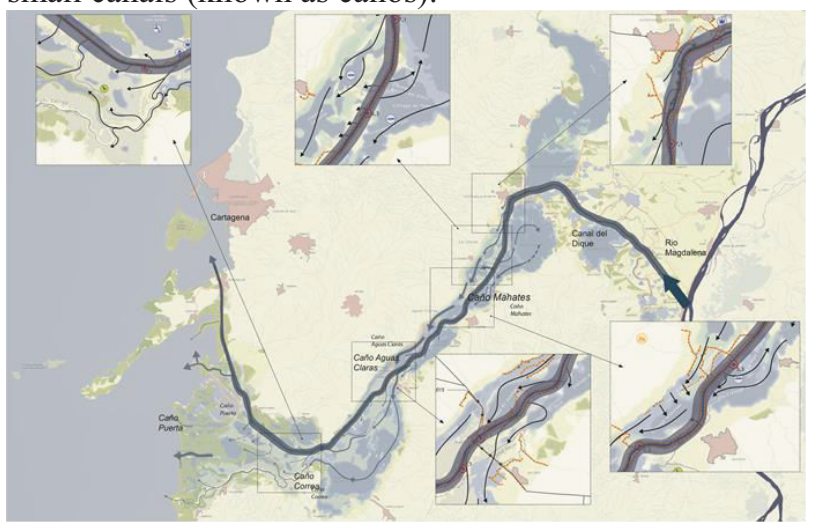

Figure 1. Overview hydraulic behaviour of the Canal del Dique system during high water conditions

In old times, the Canal del Dique valley was a flood plain of the Río Magdalena. Seasonal fluctuations in river flows transformed the valley, from a cascade of isolated ciénagas in the dry season to one large water body in the

\footnotetext{
a Corresponding author: marius.sokolewicz@rhdhv.com
}

wet season. The downstream part of the valley was a tidal salt water lagoon, in open connection with the sea, temporarily closed off by sand bars. The salt water is still found in the deep aquifers, and wells up in times of drought.

In the 17th and 18th century connections between ciénagas were created, starting downstream. At a certain moment in the past, a permanent connection with the Rio Magdalena was created; this leads to permanent inflow of water and sediment into the Canal del Dique and outflow into the bays of the Caribbean Sea. In the 17th century, the canal had a more or less meandering pattern. Large scale works in the 20th century cut out most of the meander bends, creating a nearly straight, prismatic canal for navigation purposes [1].

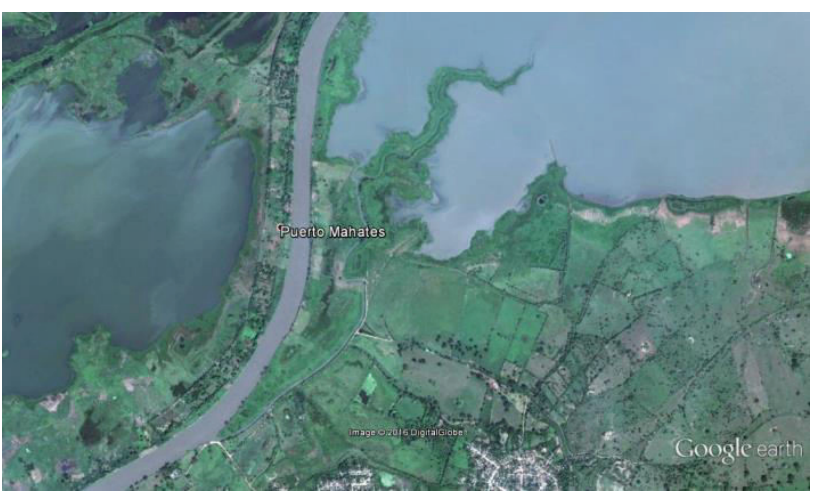

Figure 2 Caño Mahattes forming an inner delta in Ciénaga Capote as a result of large sediment inflow 
Due to human intervention a number of ciénagas were isolated from the canal by a lockable weir; this area is known as reservoir Guajaro.

The last large construction works were finished in 1984, during which 43 river bends in the canal were cut off, reducing the total length of the canal from about 152 to $117 \mathrm{~km}$. As a result, the discharge and the sediment load in the Canal increased significantly. Deposition of sediment in the canal, the ciénagas (see Figure 2) and in the bays of Cartagena and Barbacoas led to ecological deterioration and high dredging costs [1].

In December 2010, the dike on the right bank of the Canal breached resulting in an inundation of 35,000 ha of land and rendering thousands of people homeless, see Figure 3.

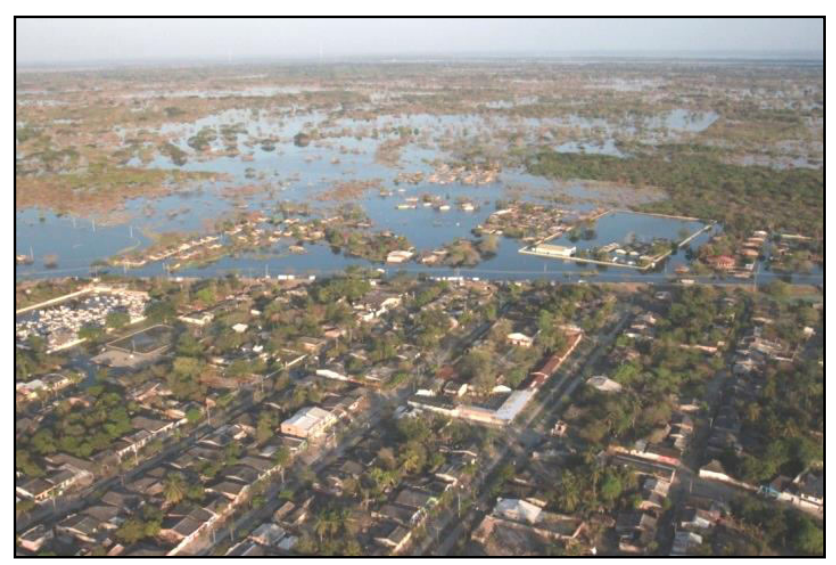

Figure 3. Santa Lucia town flooded in December 2010

\subsection{Environmental restoration project}

The 2010 floods were a trigger for action from the side of the Government of Colombia. Following a decade of studies, in 2013 the Environmental Restoration of Canal del Dique project was started with the aim to develop and implement an integral solution to the problems related to the Canal, balancing the interests of flood protection, environment, navigation, agriculture and drinking water supply.

\section{Analysis of the system}

\subsection{Investigations and development of models}

A thorough analysis of the problems was required to determine the environmental baseline and to find the optimum solution meeting all project objectives. To achieve that, a massive program of investigations was started to complement the database collected in previous studies. A detailed land level map covering nearly 2,000 $\mathrm{km}^{2}$ was constructed using Lidar technology. The bathymetry in the Canal and the connecting water bodies were measured using classic echo-sounding techniques. Extensive surveys were carried out to measure discharges, sediment concentrations and transport. Salinities in the project area were monitored monthly and vertical salinity profiles were collected to determine salinity intrusion. 16 automatic hydrographic stations were deployed to register continuously water levels in the Canal and ciénagas. Furthermore, an extensive data collection of ecological and water quality parameters was carried out.

The collected information was used to develop a set of very detailed numerical models, comprising a 1D2D SOBEK model of the Canal del Dique system and the Rio Magdalena from Calamar to its mouth (hydrodynamics \& salt intrusion), 2D SOBEK-WAQ suspended sediment and water quality model of the Canal system, 3D Delft3D hydrodynamic and sediment models of the bifurcation point and the coastal zone (see Figure 4).

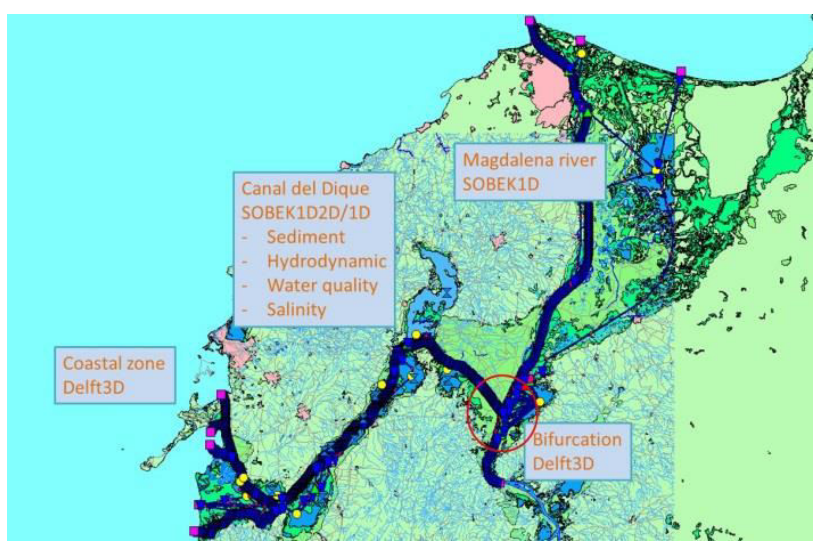

Figure 4. Different numerical models developed by the environmental restoration project

The hydrodynamic models were calibrated to an accuracy of 10-15 cm RMSE making them a reliable tool for flood hazard mapping and flood control [2].

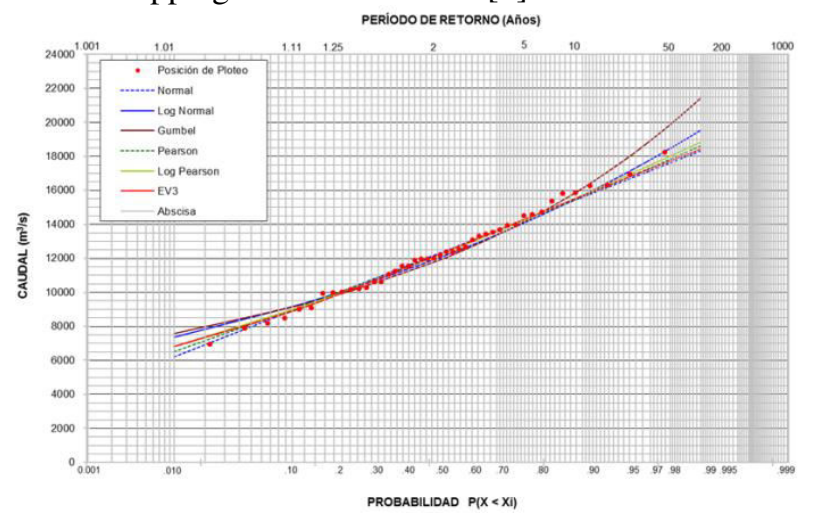

Figure 5. Extreme discharge statistics of Rio Magdalena in Calamar

Establishing the extreme water level statistics turned out to be a challenge. The hydrometric station in Calamar on Rio Magdalena close to the entrance to the Canal, has daily records of water levels dating back to 1930's. However, the migration of large river islands in the Rio Magdalena close to Calamar strongly influences the relationship between the occurring discharge and the observed water level, making the rating curve in Calamar to change in time. To determine the design (1/100 per year) water level in Calamar, first the statistics of 
discharge as an independent variable had to be established (Figure 5), and only then the corresponding $1 / 100$ per year water level could be derived (direct estimation from measured water levels would be unreliable as the enlargement of the Canal in 1980's has large impact on the water levels upstream). This was solved by deriving a new rating curve using all available discharge measurements and establishing the limits of this variability which ranged $\pm 10 \%$. Selecting the discharge measurements occurring in the period close to the catastrophic year 2010 showed that the "average" rating curve was representative for that period, therefore that curve was used to establish the statistics. The December 2010 discharge was found to correspond to 82 years return period.

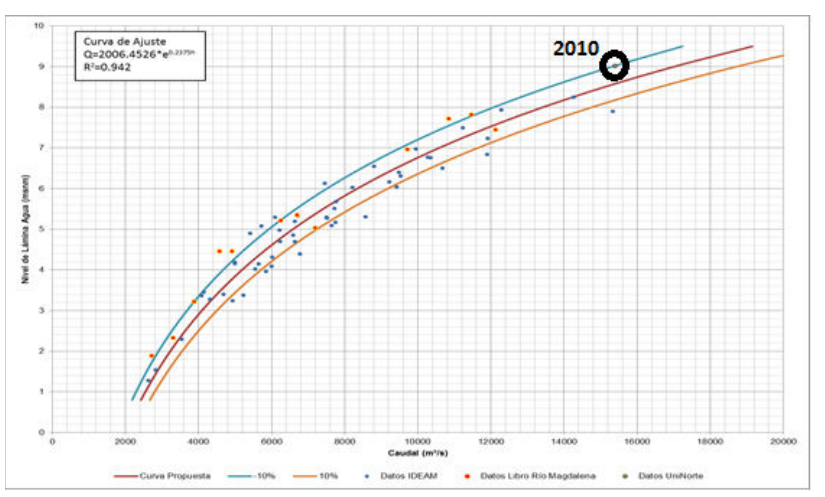

Figure 6. Rating curves for Calamar

\subsection{Modelling studies}

The developed numerical models were used to establish the environmental baseline for the project, to analyse the system and to test different solution alternatives. This analysis comprised hydrological balance, hydrodynamics of the system, sediment transport, salt intrusion and water quality. An important aspect of these studies was the flood hazard assessment, which was used to determine the location and level of urgent protection works.

The SOBEK 1D2D model was used to simulate the 2010 flood. The results of simulation (Figure 7) were compared to the (scarce) information from the field, mostly reports from villages which were either flooded or not flooded. After the solution alternatives were defined (see Chapter 3), they were also assessed for flood hazard.

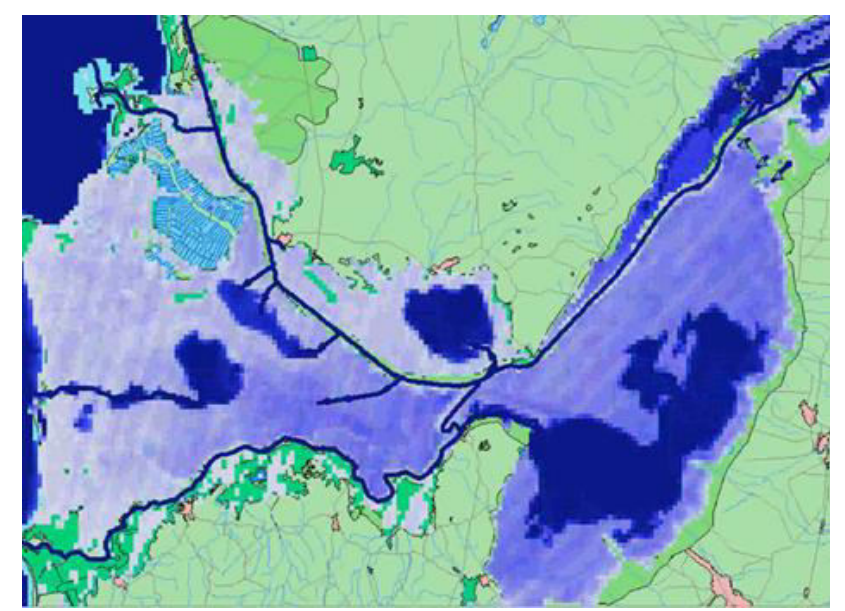

Figure 7. Example flood map

\subsection{Temporal climatic variations}

\subsubsection{El Niño and La Niña}

The short term climatic variations in the discharge in the Rio Magdalena are very much related to the El Niño and la Niña climatic phenomena. The 2010 flood event for instance was related to the La Niña period lasting from summer 2010 - early 2013. Recent years, and in particular 2015 and early 2016 are defined as a strong El Niño, resulting in extremely low discharge in the Rio Magdalena, and in drying up of ciénagas as a result of closure of the caño connections and lack of sufficient rainfall to feed the ciénagas. Figure 8 shows the water level variation in the Rio Magdalena at Calamar for three years representing the typical behaviour during El Niño and La Niña climatic phenomena. Transitions from El Niño to La Niña are not calendar limited, the year 1998 shows strong El Niño at the beginning of the year and La Niña at the end of the year. Whereas other years 1999 are fully influenced by La Niña.

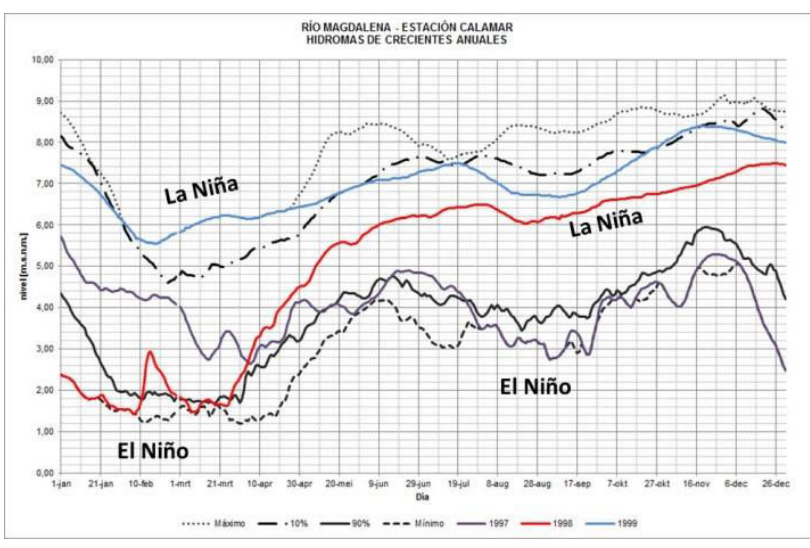

Figure 8. Water level variation in the Rio Magdalena at Calamar for three years representing the typical behaviour of El Niño and La Niña climatic phenomena. 


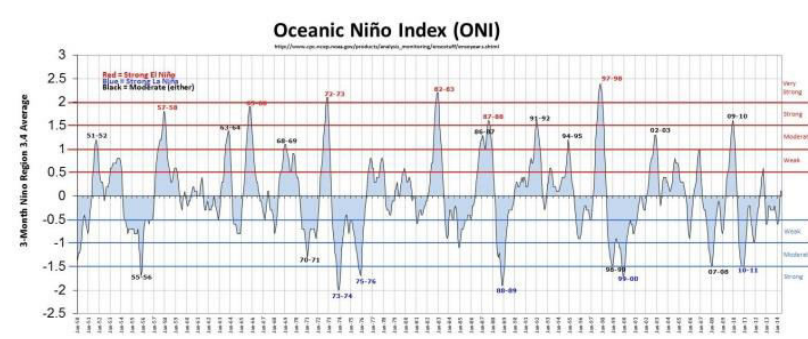

Figure 9. variations in the Oceanic Niño Index (ONI) indicating the El Niño and La Niña phenomena.

Figure 9 shows the direct relations between the Oceanic Niño Index (ONI) and the records of water levels at Calamar. The ONI index is a measure for the cyclic behaviour of average sea water temperature [3].

\subsubsection{Impact on river discharge}

On the long term, climate change further affects the discharge in the Rio Magdalena. The climate change in the Magdalena River was studied to define the future requirements of the system in terms of water supply and flood threat. The literature survey showed that climate change in the Magdalena basin is expected to bring a change in the seasonal variability in climatic conditions, leading to higher temperatures, longer dry periods and more extreme wet periods.

An article published by Nakaegawa \& Vergara [4] (referred to in the Fifth Assessment Report of IPCC [5]) gives a good view on expected changes in precipitation, evaporation, surface runoff patterns in the Rio Magdalena catchment and the resulting changes in river discharge (temporal as well as in magnitude) of the Magdalena River. The main conclusions based on the latter study are:

- The average river discharge in the Río Magdalena will decrease in the coming century;

- Discharges in the months February-April will decrease with $10 \%$ (around $-400 \mathrm{~m} 3 / \mathrm{s}$ )

- Discharges during the first peak in June-July will increase with $10 \%$ (around $+850 \mathrm{~m} 3 / \mathrm{s}$ )

- Discharges during the second peak in NovemberDecember will decrease with $12 \%$ (around $850 \mathrm{~m} 3 / \mathrm{s})$.

It was concluded that the maximum increase of $10 \%$ for peak discharges should be used to include also the effect of climate change on the river discharges of the Río Magdalena. Also 10\% increase was adopted for the extreme discharges. This was in agreement with the analysis of Future Water [6] which found an increase of $10 \%$ of precipitation in the Magdalena basin.

\subsubsection{Sea Level Rise}

The Mean Sea Level near Canal's mouth in the Bay of Cartagena shows a trend of rise (Figure 10) which is nearly double of the eustatic Sea Level Rise (SLR).
(Torres et al.) [7] found that the SLR in Cartagena for the period 1993-2010 is $5.3 \pm 0.3 \mathrm{~mm}$ compared to $1.7 \pm 0.1$ $\mathrm{mm}$ SLR in Cristobal at the Caribbean coast of Panama. This indicates large influence of tectonic movements on the relative SLR.

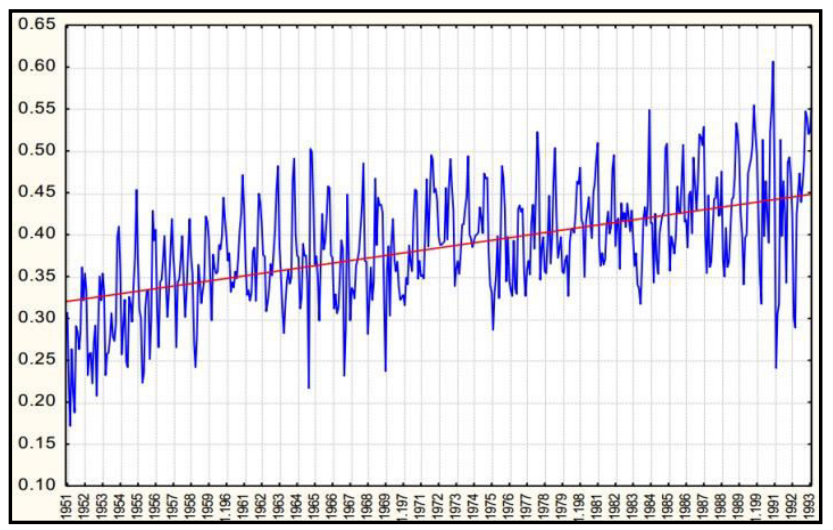

Figure 10. Trend in Sea Level Rise for Cartagena Bay, Consorcio Dique.

The global eustatic SLR predictions of IPCC [5] give an upper range of $82 \mathrm{~cm}$ in 2010. Extrapolation of this trend to a figure of $96 \mathrm{~cm}$ in 100 years. Considering the tectonic movements, but also large uncertainties in the predictions, a SLR of 1 meter in 100 years was assumed in the project.

Such rise of sea level could have a huge impact on the low-lying delta, see Figure 11. It could be expected, however, that in a sedimentary system the land in the delta will be built up with mangrove vegetation trapping sediments, which will partly compensate the impact of rising sea level [8], [9].

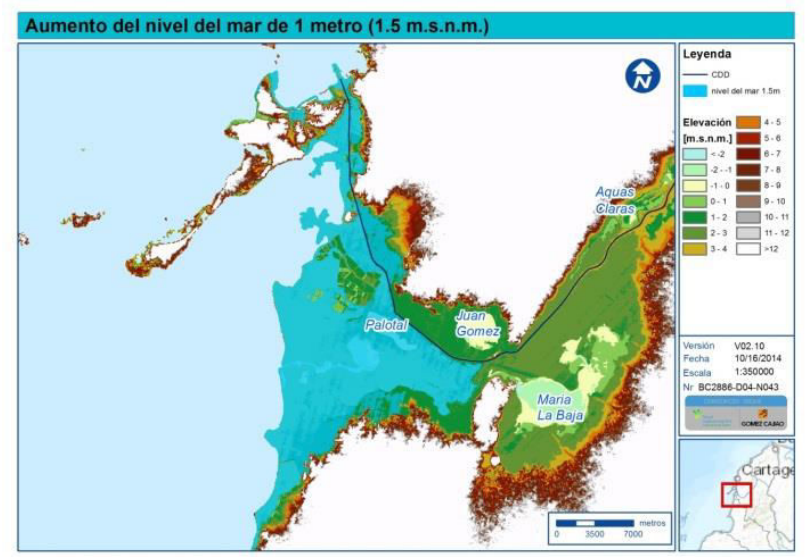

Figure 11. Flooded area in the delta of Canal del Dique with SLR of $1 \mathrm{~m}$ [9]

In order to establish the impact of SLR, the project established the Mean Sea Level (MSL) in Cartagena in the period 2008-2013 to the national datum (msnm, meters above sea level in Buenaventura on the Pacific coast of Colombia). This relationship had never before been derived for the Caribbean coast of Colombia. By referencing the hydrographic station in Cartagena to 
msnm, MSL was established to be $0.35 \mathrm{~m}$ above msnm.[2]

\section{Study of alternatives}

Three basic alternatives were constructed, all fulfilling the project's objectives. In all alternatives, a control structure near Calamar regulates the discharge entering the Canal. It is operated in such a way that it mimics the natural hydrograph with two high water peaks in June and November, allowing for flushing the ciénagas while topping-off high discharges (see Figure 12), providing for flood protection.

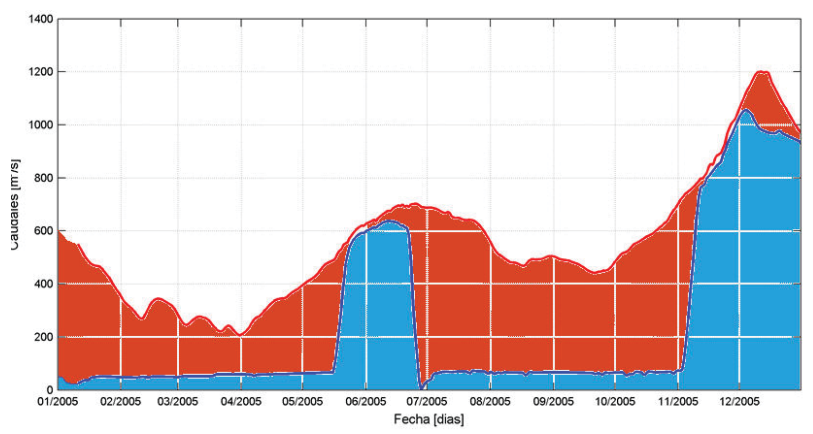

Figure 12. Controlled hydrograph in Canal del Dique

Alternative 1 consists of one regulating structure in Calamar, which allows for reduction of volume of water and sediment entering the Canal. Water and sediment follow the same path as in the present situation. The base flow is just enough to ensure the minimum water depth for navigation in the Canal. To prevent emptying of the ciénagas, the open caño connections are closed. Inflow of water into the ciénagas is regulated by an inflow section at the upstream of the ciénagas to mimic the historic cascade-wise flow pattern.

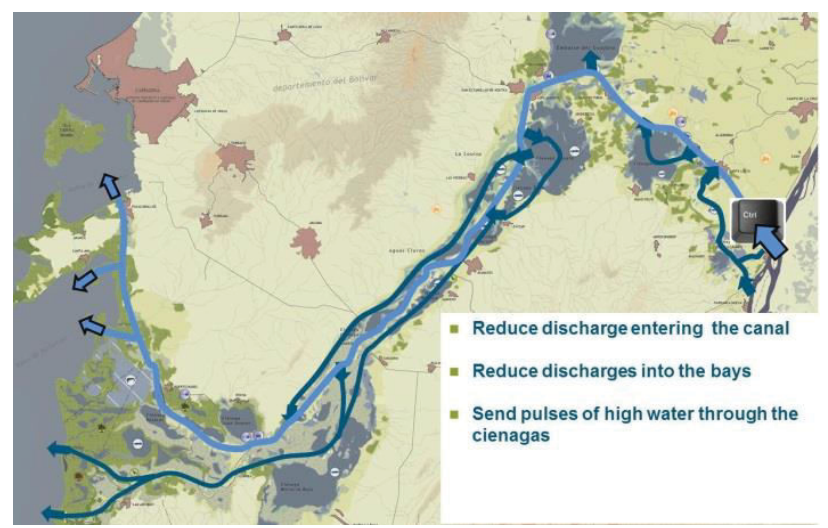

Figure 13. Alternative 1

In Alternative 2 a control structure is added at the downstream end of the Canal (at Puerto Badel), preventing any flow from the Canal into the Cartagena and Barbacoas bays. The base flow is directed through caño Correa in the delta to ensure the water level in ciénagas and to prevent salt intrusion. At flood stage, excess water is directed over the delta.

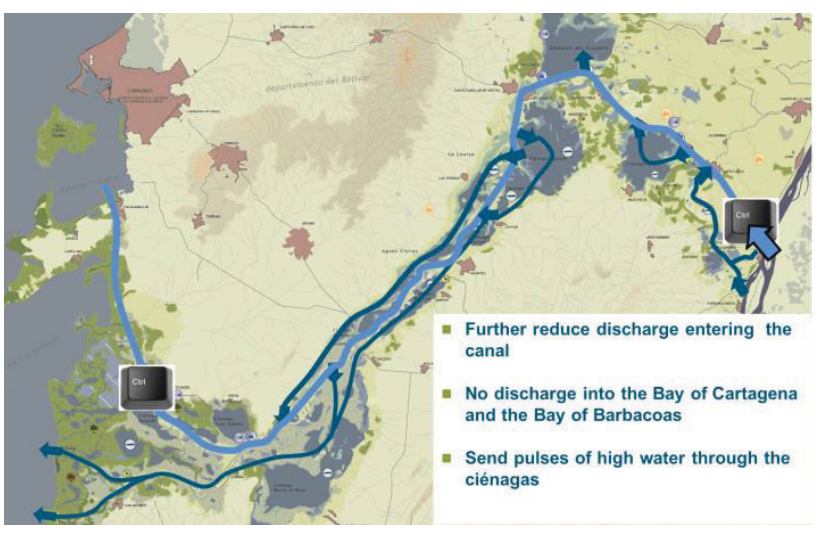

Figure 14. Alternative 2

In Alternative 3, another control structure is added in the middle of the system. This creates a cascade system consisting of two compartments in which the water level can be fully controlled without requiring large volumes of water. Parallel to the Canal lies a cascade system of connected ciénagas that functions independently of the Canal (stagnant water in the canal while water flowing through the ciénagas).

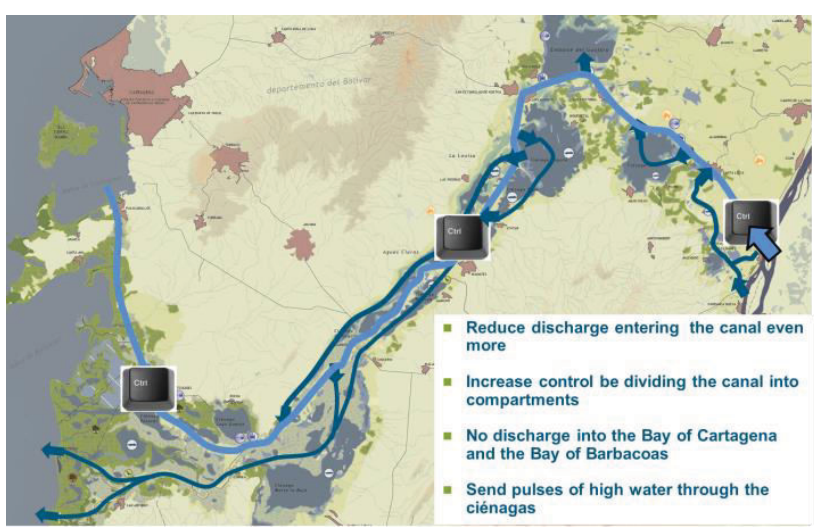

Figure 15. Alternative 3

\section{Integral solution}

A solution based on principles of Alternative 2, fully fitting the project's objective, was designed in which the inlet of water from the Magdalena River is regulated by the main control structure [10]. This provides a controlled dynamics of water levels necessary for environmental purposes while keeping the extreme flows out of the Canal system. A second main structure directs the majority of the flow through the delta to the open sea, outside of the bays suffocating from sediments in the present situation. Both structures are combined with large ship locks for navigation. The water exchange between the Canal and ciénagas is controlled by fixed weirs. These structures assist in mimicking the natural behaviour of water level variation in the ciénagas and flow orientation through the ciénagas, allowing uniform flushing of ciénagas necessary to keep them in good environmental shape. In the current situation most ciénagas are fed by water coming through the caño, often 
located at the downstream end of the ciénagas, limiting the equal distribution of the incoming water.

The first gate is located in the Canal del Dique at 3.2 $\mathrm{km}$ from the entrance near Calamar and is accompanied by a ship lock (see Figure 16). The gate will consist of 3 openings of each 20 meters wide. The lower crest level is located at $-1 \mathrm{msnm}$.

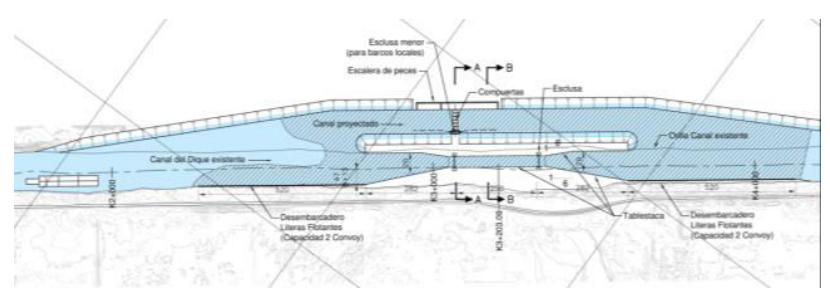

Figure 16. Control structure in Calamar

\section{Control system}

The control structures will be managed by an automated system. This system, based on SCADA and Delft-FEWS flood forecasting software and advanced statistics, uses the hydrographic stations along the Magdalena River and in the Canal to predict water levels near the bifurcation point. A fixed set of operating rules has been derived. Together with real-time and forecasted water levels, the optimum management choice will be determined on daily basis and the control structures can be adjusted accordingly.

The operation rules are based on required water levels at Incora ( $7 \mathrm{~km}$ from the entrance near Calamar), a few kilometers downstream of the gate. The required water level at Incora has been derived from system requirements such as minimum water levels to connect the Canal with ciénagas and Embalse Guajaro. Figure 17 shows the water levels and corresponding discharges at Incora for the year 2005. The pattern of the controlled inflow is defined by 3 flows:

- $\quad$ Base flow (1.83 msnm at Incora): Minimum level necessary for navigation.

- Medium high peak flow (varying water level around 5.2-6.0 $\mathrm{msnm}$ ): Used for filling of the large reservoir (Embalse Guajaro). Duration around 30 days.

- $\quad$ High peak flow (7.00 msnm at Incora): Used for flushing ciénagas, during a maximum of 50 days.

The possibility of bringing in water from the Magdalena River into the Canal del Dique is largely determined by the water level in the Rio Magdalena in front of the entrance with the Canal del Dique. In case water levels at Calamar reach extreme levels (like 2010) the gates will be opened until the water level at Incora reaches the limit of $7.0 \mathrm{msnm}$ and then closed, allowing only environmental flow to pass. The extreme water levels in the Río Magdalena near Calamar, upstream of the Canal entrance, will increase by $10 \mathrm{~cm}$ because of closing the Canal.
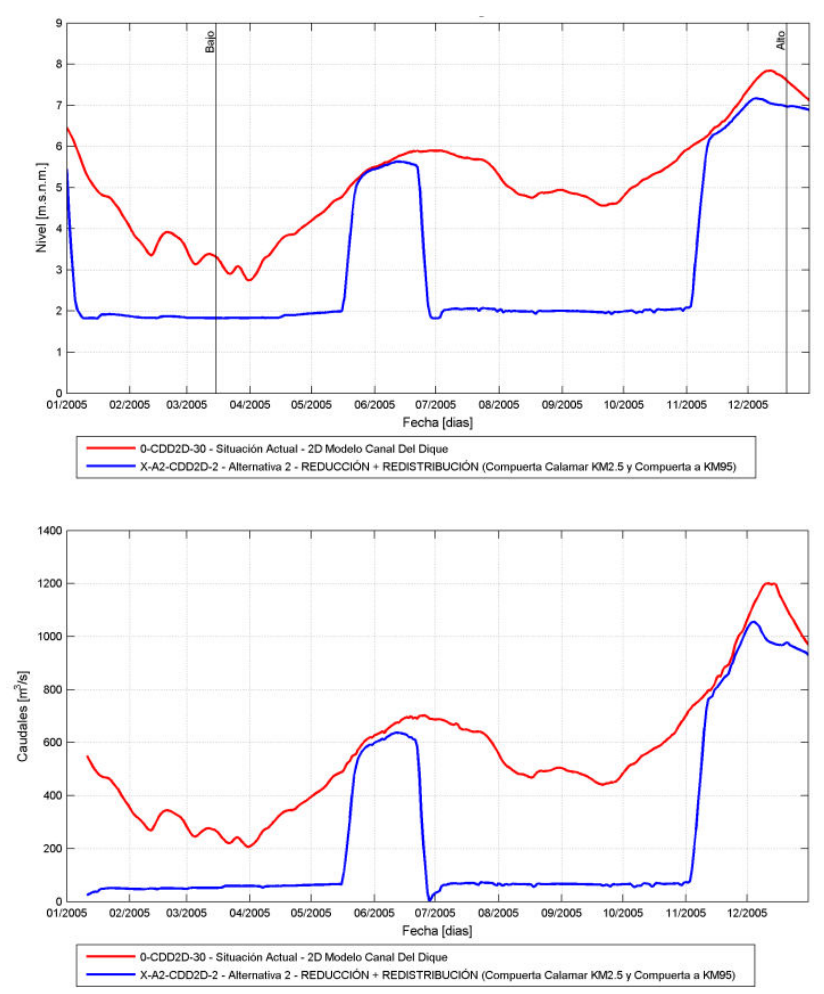

Figure 17. Water level near Incora (top) and discharge entering the Canal Del Dique (bottom) in the present situation and with the control structure.

It is not allowed to let more water into the Canal Del Dique system than the discharge necessary for the 7.0 msnm at Incora. Exceeding the maximum water level at Incora of $7 \mathrm{msnm}$ leads to flooding of villages along the ciénagas in the Canal del Dique system. The operational rules of the gate are such that the maximum water level cannot be exceeded. In wet years it is possible to bring in a relatively high discharge for a longer period of time for the benefit of the dynamics in the ciénagas without compromising on the maximum acceptable water level at Incora.

\section{Conclusion}

Numerous natural disasters happening in the Canal del Dique system in the last couple of years clearly show the urgent need for a large scale intervention. Restoration of the environmental system aims at improving the water system with respect to its most important functions: navigation, ecology of ciénagas, water quality in the bays of Cartagena and Barbacoas and flood protection of the entire area. The proposed solution reduces the inflow of water and sediment into the Canal del Dique and tops off the peak discharge to ensure flood safety. It redistributes water in the system to better facilitate various system functions. 


\section{Acknowledgements}

This article is based on work carried out by Consortio Dique, a joint venture of Royal HaskoningDHV of the Netherlands and Gomez Cajiao of Colombia under the assignment from Fondo Adaptación. Deltares was involved in the project as a technical advisor and quality reviewer.

\section{References}

1. Mogollón Vélez J.C. (2013). El Canal Del Dique historia de un desastre ambiental, El Áncora Editores Bogotá, ISBN 978-958-36-0149-1

2. Consorcio Dique (2015). Recalibración de los modelos hidráulicos del Canal del Dique, CD.IB.121.MOD.INF.00-005

3. http://www.cpc.ncep.noaa.gov/products/

analysis_monitoring/ensostuff/ensoyears.shtml, accessed on 22.02.2016

4. Nakaegawa T. and Vergara W. (2010). First Projection of Climatological Mean River Discharges in the Magdalena River Basin, Colombia, in a Changing Climate during the $21^{\text {st }}$ Century. Hydrological Research Letters, 50-54.

5.IPCC (2013). Climate Change 2013: The Physical Science Basis. Contribution of Working Group I to the Fifth Assessment Report of the Intergovernmental Panel on Climate Change.

6. Future Water, Sar Vision, UNESCO IHE, Deltares (2014). Climate adaptation Colombia, Scaling of climate data for the Magdalena basin.

7. Torres, R. Ricardo; Tsimplis, Michael N. Sea-level trends and interannual variability in the Caribbean Sea. Journal of Geophysical Research: Oceans, 118 (6). 29342947

8. Krauss, K. W., McKee, K. L., Lovelock, C. E., Cahoon, D. R., Saintilan, N., Reef, R. and Chen, L. (2014). How mangrove forests adjust to rising sea level. New Phytologist, 202: 19-34. doi: 10.1111/nph.12605

9. Consorcio Dique (2014). "Estudios Básicos: Informe de cambio climático, CD ID 113 HIDR INF 00-002-C2 10. Consorcio Dique (2015). Desarrollo, evaluación y selección de las alternativas, CD.IB.120.MOD.INF.00002 